\title{
Collieries and Agricultural Labour in Nineteenth-Century Northumberland
}

\author{
Michael C. Kelly
}

\begin{abstract}
Since the early nineteenth century, contemporary observers and historians have argued that the apparent dichotomy in agricultural living standards between a seemingly prosperous northern England and an impoverished south was primarily caused by the new industrial sectors which developed in the north of England between $\mathbf{1 7 8 0}$ and the mid-nineteenth century. In Northumberland, the dominant industrial sector was coal mining. This paper challenges the assumption that coal mining was the principal factor in elevating agricultural wages in Northumberland. On the contrary, the mining sector played only a minor role in establishing agricultural wages in Northumberland, and there is evidence that day wages had little impact on agricultural living standards in the region during the nineteenth century.
\end{abstract}

Index Terms-Agricultural labourers, coal mining, northumbrian history, Industrialisation.

\section{INTRODUCTION}

In January 1851, James Caird and his companions, walking over green English hills, then down into a picturesque valley, came upon a small village of three hundred inhabitants. To Caird's shock and disgust he noticed that the village and its surrounds were completely filthy. Piles of rubbish lay strewn around the cottages and against the walls. Outside, pigsties were constructed beneath the only window (and therefore the only source of ventilation) of the lodgings, and to Caird's horror he realised that the cottagers shared their dank premises with horses, pigs and cows [1]. Yet this squalid village was not in the depths of William Cobbett's impoverished south, such as Dorset and Wiltshire. This was the village of Wark Castle, Northumberland, deep in the heart of what even Caird defined as the 'prosperous' north of England [1].

Caird and Cobbett were not alone in making a bi-polar analysis of English agricultural conditions. Most of their contemporaries, and the vast majority of historians since, have accepted the premise that England was, in a sense, two nations, when it has come to an analysis of the condition of agricultural labour: the predominantly rural south, dominated by agricultural distress and the overwhelming poverty of agricultural labourers, and a rapidly industrialising north with high agricultural wages and an improved standard of living relative to the south. Yet if this vision of England in the early to mid-nineteenth century is valid, how does one account for the anomaly of Wark Castle?

In an analysis of the north-eastern county of Northumberland in the period from c1780 to 1850 it is

Manuscript received June 30, 2013; revised October 5, 2013.

Michael C. Kelly is with the Nazarbayev University, Astana, Kazakhstan (e-mail: mkelly@nu.edu.kz). important to examine and challenge the notion - held from the days of Cobbett and Cairns until the present, and epitomised by the north-eastern scholar, Norman McCord - that it was the proximity of other forms of employment, particularly those recently developed following the processes of industrialisation, which created high wages in the north-east and therefore created a higher standard of living for agricultural labourers relative to the south and east [2].

Commentators from Caird to the present day have been convinced that there was greater prosperity in the agricultural districts of the north of England than in the south. The key contributing factor, in their opinion, was the development of industry in the north with its inflationary effects on wages in the surrounding agricultural districts and its propensity to absorb surplus labour in agricultural zones. In this manner the agricultural labour supply was minimised and therefore wages, as well as living standards, increased. Caird, in referring to the 1848 Poor Law returns, noted that the average percentage of paupers in northern communities was only 6.2 whereas in the south the average was 12.1 . He attributed this directly to the territorial demarcation of coal in northern England and its new related industries [1]. William Cobbett was convinced that the lack of industries in the south, such as in the villages of the valley of Avon, led directly to rural impoverishment [3], as did Edward $\mathrm{P}$ Thompson, noting similar problems in East Anglia, the West country and the south in general [4]. Michael Flinn also attributed what he believed were higher wage rates in the north to industrialisation [5] and Norman McCord was convinced that, as alternative industrial employment was available, farm workers in the north earned better wages [6]. In Northumberland the key industry was coal mining.

\section{BODY PART}

According to John Buddle, a Northumbrian colliery viewer, in 1829 there were 11,954 workers engaged in mining in the zone of the River Tyne. Of these, almost eight and a half thousand worked underground. There were a further nine thousand employed on the River Wear, making a total of approximately twenty-one thousand men and boys engaged in the industry [7]. By 1851 this figure had reached over forty-one thousand [2]. There were, naturally, other industries, but their capacity to employ was rather limited in comparison. Iron production was one such industry. John Donaldson Selby commented that the iron foundries of Tweedmouth Old, Tweedmouth New and Helen Iron Foundry at Spittal employed only 215 workers between them [8]. Even as late as 1850 the largest of the foundries, at Bedlington, employed only two thousand workers [8]. Similarly, the chemical manufacturers on the Tyne, while employing half the entire national workforce in this industry, employed only 3,067 people by the 1850s [8]. The seven lime 
kilns and quarries on the border of Northumberland and northern Durham employed a total workforce of only 162 people [8] and leadworks, while more common in Durham, offered little employment in Northumberland: as late as 1855 only five lead works were in operation at Newcastle [9]. Later engineering and shipbuilding would dominate the Tyne, but most plants, such as the engineering company of Armstrong, Whitworth \& co. at Elswick, did not appear until the late 1840 s and therefore could not provide alternative employment to agriculture in the early decades of the nineteenth century [10]. Thus, the principal alternative employment source to agriculture in Northumberland was, clearly, coal mining. If agricultural wages and living standards were to rise as a direct result of industrialisation in Northumberland as argued, the catalyst would be mining. Moreover, this would have been the industry that would have absorbed surplus agricultural labour. And it was precisely this that many contemporaries and later historians argued. In 1833, according to William Blamire, MP for the eastern division of Cumberland, the farming communities in the Northumberland colliery districts were prosperous at this time, specifically because of their links with the coal industry [11], and Norman McCord was typical of many historians when he argued that large collieries such as those at Walker, as well as small collieries servicing local areas, guaranteed alternative employment for agricultural workers [2].

The available evidence, however, raises serious doubts about the effects of mining on agricultural living standards. First, it is a myth that real wages in Northumberland were inflated; and secondly, there are several reasons for discounting the theory of surplus agricultural labour absorption within the coal mining industry.

The real wage indices that so many commentators have relied upon have proven to be unreliable at best and perhaps, inapplicable to Northumberland. In the northern region of Northumberland the standard arrangement for labour was the 'hinding' system. Agricultural labourers, generally married, were hired for twelve months from spring to spring [12]. They occupied a cottage, normally attached to the farm, which was free of rent and rates [12]. Most critically, the bulk of their payment was in kind, paid principally in wheat, barley and oats, with a labourer generally keeping a cow and receiving approximately $£ 4$ in money payments annually [13] According to John Langhorne of Berwick on Tweed, labourers bargained for a fixed portion of the produce of the farm, and in this manner the average weekly earnings were calculated against the market price of produce [14]. Often this arrangement was formalised by contract, such as that on the Earl of Tankerville's property at Chillingham (see Appendix for details). According to Langhorne, this 'wage' had not changed for twelve years on the Earl of Tankerville's estates [13]. Naturally, in times of high prices payment in kind was expensive for farmers, but during periods of low prices, economical. Furthermore, as Edward Cayley MP noted, money wages were easy and quick to increase but needed a generation to pass before they could be reduced [14], whereas a reduction in grain prices automatically reduced the cost of labour under the 'hind' system. The situation on the Earl of Tankerville's estates is a case in point. While stating that the labourers' fixed portion of the produce, which was generally enough with which to maintain a family, had not changed for twelve years, Langhorne admitted in his testimony that commodity prices in the countryside had fallen prior to 1836 , yet insisted that labourers' wages were too high [13]. Logically, however, it is evident that the real value of produce (and therefore the labourers' 'wage') had fallen over the twelve years prior to 1836 . In real terms, it would seem that the 'hinds' in this part of Northumberland had seen a fall in living standards if one only considers the monetary price scale of produce. The 'hind' could benefit, however, as he received free housing and an adequate food supply for himself and his family, irrespective of food prices. The annual employment contract also guaranteed year-round employment, offering greater security than day-labour and, according to Mr. Grey of Millfield, ensured maintenance of the 'hind' even during periods of illness [12]. Therefore the true benefit to Northumbrian labourers in comparison to their southern 'cousins' was not essentially the value of a cash wage rate, but the guarantee of food and housing, regardless of market prices. Local labourers in the parish of Norham claimed in this manner they were able to make annual savings from their cash payment of between $£ 2$ and $£ 5$ annually [12]. A Mr. Nicholson of Norham claimed that 'hinds' were better off, although actually paid less in cash, than miners, fishermen, masons and carpenters [12].

Thus, the agricultural 'hind', who dominated northern Northumberland, was paid in kind with a portion of the produce of the farm, a portion that, as many contemporaries observed, did not change for several years. The real value of this 'wage', therefore, fluctuated in accordance with changes to commodity prices. Certainly from the end of the French wars until the 1840 s this meant a decline in the value of farm produce and therefore a fall in the real wage value of the 'hind's' proportion of farm produce. In effect, the average weekly wage rates of agricultural labourers in Northumberland - such as those collected by Hunt of 10s $3 \mathrm{~d}$ for the period 1794-95 and 11s 9d between 1833 and 1845 [15] - are entirely irrelevant for labourers contracted under the 'hind' system. Furthermore, as day labourers were a rarity in most of northern and eastern Northumberland, these rates can only apply to a minority of agricultural labourers, principally those residing in the southern part of the county. Even here, most were forced to emigrate from the region and those who remained worked only sporadically throughout the year and regularly only at harvest time. Moreover, most harvest workers were either itinerant Irishmen or, in farming districts close to a town, sometimes miners' wives, although even this was uncommon in the northern part of the county [9]. At best, therefore, these rates represent a small minority of agricultural labourers in the county, and more probably, they represent not average weekly earnings but simply a multiple of six times the daily wage rate, which no labourer in the county would actually have earned in practice. Even if one takes into consideration the possibility that at harvest time day workers were well paid (relative to the southern counties), it is improbable that this was caused by alternative, highly-paid employment in the mines. It is more likely that these hypothetically high day rates evolved owing to cyclical labour shortages caused by the continued survival of the 'hind' system, (for this caused depopulation in Northumberland) [12]. This cycle - the 'hind' system causing depopulation, causing in turn labour shortages, forcing in turn farmers to adopt the 'hind' system - was exacerbated by the extent of pastoralism in Northumberland. This was less labour-intensive but on the other hand required more constant employment throughout the year and thus contributed further to the survival of the 'hind' system [16]. As Caird pointed out, pastoralism at the base of the Cheviot Hills required only a 
shepherd and his wages [1], often also paid in kind [1]. If mining had put pressure on the supply of agricultural labour, it would, as Martin Daunton argued, have stimulated further reliance on the 'hind' system, not an increasing reliance on highly-paid day labourers, who were needed only at infrequent periods of the year [16]. The sparse population of Northumberland, as mentioned by most contemporary observers, was the most likely cause of hypothetically high wage rates, not inflationary pressure on wages caused by the proximity of the mines.

The second problem concerning mining and agricultural labourers is the theory that the mining industry absorbed surplus agricultural labour and therefore alleviated stress on living standards in agricultural communities. There are, however, several factors that preclude this theory. The first is the inability of agricultural labourers to transfer to coal mining. As John Wilson reported about the Tyne and Wear pit population: "Pitmen must be bred to their work from childhood; they cannot well be drilled to it at a later age; their numbers cannot be recruited from any other class...such repugnance is entertained against going down the pits by labourers of every other description, that they will rather submit to more disagreeable work at lower wages [12]."

This belief - that men were bred to the pit and therefore outsiders were unsuited for the job - was widespread within the industry [17]. A career down the pits began at the age of seven or eight when a boy would enter as a 'trapper', responsible for the ventilation doors in the shafts [18], although children as young as five were not unknown in Northumbrian pits in 1842 [8]. He would then progress through a series of jobs until, finally acclimatised to pit conditions, he became a hewer [16]. There was very little likelihood that an outsider would enter the pits as an adult.

This, however, was not the only impediment to an outsider entering the pits. Until 1844 all miners in Northumberland were bound to an annual contract known as a Bond [19]. The contract ran from April to April and allowed only a two-week period for renegotiation of contracts known as 'binding time' [7], [19]. As well as limiting the contracting opportunities for agricultural labourers to one fortnight a year, the Bond also tended to develop a 'skilled caste' mentality against outsiders amongst pitmen [16], further limiting the scope for entry into the trade for agricultural labourers. The intensity of this 'caste' feeling can be observed in the mass adherence in 1826 to the Association of Colliers on the Rivers Tyne and Wear by over four thousand miners [8].

In the industry itself, there were also two fundamental structural problems which would have tended to preclude entrance of agricultural labourers into the pits. First, following open competition resulting in over production of coal, mines were forced to limit hewing, while some smaller collieries employed men for only three days a week by 1830 [7]. Wages therefore fell from 1815 to 1830 and precipitated a crisis in the industry [7]. To add to the problem there was a natural increase in internal population growth within the collieries without any outside pressure from agricultural workers. A Mr. Reay, coal agent to Mr. Russell of Brancepeth, stated in 1834 that a pit population of 125 families could provide twenty to twenty-five young adult hewers annually to a single colliery; an adequate number for internal growth [12]. With over production, low price levels and underemployment within the industry, absorption of surplus agricultural labour was improbable. The second structural problem concerned mobility of labour. It was estimated by J. R. Leifchild that every year twenty-five per cent of Northumbrian pitmen transferred en-masse to other pits in what were known as 'shiftings' [8]. Slumps in production at one pit and new or increased production at another would therefore find an equilibrium without resorting to labour from outside the industry. The mobility of miners can be gauged by the fact that only eight per cent of Wallsend's mining population of 667 residents between 1798 and 1812 was born in the parish [19]. Most had migrated there from other collieries. Furthermore, poaching of miners by one company from another was endemic even though outlawed by the 1805 Coal Owners' Agreement [19]. Another form of mobility came from the lead miners of Durham. John Wilson noted that in the district of Teesdale many lead miners were forced to migrate to collieries as the local parishes refused to make up their insufficient wages [12]. Mr. Little of Stanhope concurred, noting that in Weardale a downturn in lead prices had caused a similar migration to the colliery districts [12]. And finally, even after periods of intense crisis leading to strikes, the colliery labour force was not recruited from Northumbrian agricultural labourers. Following the strike of 1831-32 miners were brought in from Wales, Staffordshire and Yorkshire to replace local pitmen [8] and during the 1844 strike Irishmen were brought in to work the mines [20]. The structural problems of mobility and underemployment within the mining industry, therefore, tended to preclude the involvement of surplus agricultural labour in coal mining.

There is one further issue in relation to mining and agricultural labour that needs attention. Historians such as Norman McCord have argued that mining was accessible to rural workers owing to the similarities in the use of equipment and methods in both industries, particularly the employment of horses. He therefore postulated a considerable amount of overlap and movement between rural employment and mining [2]. This theory overstates the volume of such employment that mining could absorb from the rural sector. In 1802 at the East Kenton colliery, out of a workforce of forty-two men and boys, twenty-three were hewers, twelve were putters, three were trappers and only four worked with horses [21]. After thirty-nine years there had been no improvement in the industry. At Walbottle colliery, of 361 employees at the pit, only two below ground worked with horses and only four above ground worked in the capacity of general labourers [8]. In the intervening years, the stationary steam engine had replaced horses for winding tasks in shafts and above ground had replaced horse-drawn coal trucks [21]. By about 1841 engine power had been introduced underground wherever possible, further reducing the use of horse power, although horses were never completely dispensed with during the nineteenth century [22]. The opportunities for agricultural labourers to transfer into the mining sector in the capacity of a livestock handler were therefore relatively insignificant and could not account for a vast absorption of surplus agricultural labourers within Northumberland.

\section{CONCLUSION}

In Northumberland it is therefore incorrect to assert that industrialisation had caused inflated real wage levels in the 
agricultural sector. It is equally invalid to claim that large numbers of surplus agricultural labourers were absorbed into local developing industries. In Northumberland the principal industry was coal mining and it did not create wage inflation in the agricultural sector, nor for reasons of inaccessibility, lack of acclimatisation, contractual difficulties, 'caste' resistance and structural problems of underemployment and internal mobility, did mining absorb surplus agricultural labour.

\section{APPENDIX}

A Northumbrian 'Hind' Contract [14]. 'I agree to serve the Earl of Tankerville as a servant in husbandry or a common labourer, at Chillingham, from the $13^{\text {th }}$ of May 1835 to the $13^{\text {th }}$ of May 1836, upon the following conditions: to have six bolls of oats (a boll is six bushels), three bushels of wheat, half a stone of cast wool, four bolls of barley, one bushel of rye, one boll four bushels of peas, five bolls of potatoes, one cow kept, 41 in money, six stones in pork, in lieu of keeping a pig, or hens or other poultry; and I further agree that my cow shall stand in the common cow-house, and that I will find a sufficient woman to work, when called on, for 1s a day, for 40 days in harvest, and $8 \mathrm{~d}$ for every day's work the remainder of the year." "Witness my hand, this $2^{\text {nd }}$ of March 1835." (signed) John Paes "Witness," John Jackson.

\section{REFERENCES}

[1] J. Caird, English Agriculture in 1850-51, $2^{\text {nd }}$ ed., London, UK: Frank Cass and Co. Ltd., 1968, pp. 474-475, 511-514

[2] N. Cord, North East England: An Economic and Social History, London, UK: Batsford Academic, 1979, vol. 35, no. 38, pp. 26-27.

[3] W. Cobbett, Rural Rides, vol. 2, London, UK: J.M. Dent \& Sons, 1925, pp. 53.

[4] E. P. Thompson, The Making of the English Working Class, $4^{\text {th }}$ ed. London, UK: Penguin, 1991, pp. 245.

[5] M. W. Flinn, "Trends in Real Wages, 1750-1850," Economic History Review, vol. 27, pp. 404, 1974.

[6] N. Cord, British History 1815-1906, Oxford, UK: Oxford University Press, 1991, pp. 108.

[7] Select Committee of the House of Lords Report on the State of the Coal Trade, (1830), British Parliamentary Papers, Fuel and Power: Coal Trade, vol. 1, Shannon, Ireland: Irish University Press, 1969, pp. $54-69$

[8] Children's Employment Commission Appendix to First Report of Commissioners, Mines. Part I. Reports and Evidence from sub-Commissioners, (1842), British Parliamentary Papers, Industrial Revolution, Children's Employment, vol. 7, Shannon, Ireland: Irish University Press, 1968, pp. 516-518.

[9] J. Long, Conversations in Cold Rooms: Women, Work and Poverty in Nineteenth Century Northumberland, Bury St. Edmunds, UK: The Boydell Press, 1999, pp. 57-82.

[10] L. Aberconway, The Basic Industries of Great Britain: Coal, Iron, Steel, Engineering, Ships. An Historic and Economic Survey, London, UK: Ernest Benn Ltd., 1927, pp. 162-163.

[11] Select Committee Report on Agriculture, (1833), British Parliamentary Papers, Agriculture, vol. 2, Shannon, Ireland: Irish University Press, 1968, pp. 307.

[12] Royal Commission into the Poor Law, Report, (1834), Appendix A, British Parliamentary Papers, Poor Law, vol. 8, Shannon, Ireland: Irish University Press, 1968, pp. 409-410, 413-414

[13] Select Committee Second Report on Agricultural Distress, (1836), British Parliamentary Papers, Agriculture, Shannon, Ireland: Irish University Press, 1968, vol. 3, pp. 181-253.
[14] Select Committee House of Lords on the State of Agriculture, (1837), British Parliamentary Papers, Agriculture, vol. 5, Shannon, Ireland Irish University Press, 1968, pp. 223-247.

[15] E. H. Hunt, "Industrialisation and regional inequality: Wages in Britain, 1760-1914," Journal of Economic History, vol. 46, pp 965-966, 1986

[16] M. J. Daunton, Progress and Poverty: An Economic and Social History of Britain, 1700-1850, New York: Oxford University Press, 1995, pp. 225-226.

[17] Durham County Records Office, National Coal Board Papers, I/JB/1786 in The Struggle for Market Power: Industrial Relations in the British Coal Industry, 1800-1840, James A Jaffe, Cambridge, UK Cambridge University Press, 1991, pp. 86.

[18] Children's Employment Commission, First Report of the Commissioners, Mines, (1842), British Parliamentary Papers, Industrial Revolution, Children's Employment, vol. 6, Shannon, Ireland: Irish University Press, 1968, pp. 18.

[19] J. A. Jaffe, The Struggle for Market Power: Industrial Relations in the British Coal Industry, 1800-1840, Cambridge, UK: Cambridge University Press, 1991, pp. 74-76.

[20] Report of the Commissioner Appointed under the Provisions of the Act 5 \&6 Vict. c. 99, to Inquire into the Operation of the Act, and into the State of the Population of the Mining Districts, (1846), British Parliamentary Papers, vol. 24, pp. 19.

[21] F. Atkinson, The Great Northern Coalfield 1700-1900: Illustrated notes on the Durham and Northumberland Coalfield, London, UK: University Tutorial Press Ltd., 1968, pp. 47-52.

[22] G. C. Greenwell, Glossary of Terms Used in the Coal Trade of Northumberland and Durham, 1888, in F. Atkinson, The Great Northern Coalfield 1700-1900: Illustrated Notes on the Durham and Northumberland Coalfield, London, UK: University Tutorial Press Ltd., 1968, pp. 36.

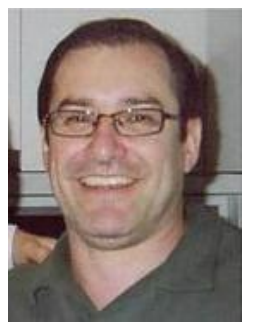

Michael C. Kelly was born in Newcastle, England in 1962. He completed a PhD in modern European history-with a specialisation in ideological struggle — at the University of Melbourne, Australia in 2005. He lectured in the History Department at the University of Melbourne, the School of Social Sciences at Victoria University, Melbourne and the Department of History at National University of Singapore before joining Nazarbayev University in Kazakhstan in 2011.

$\mathrm{He}$ is an Associate Professor in the School of Humanities and Social Sciences, where he serves as Head of Humanities and teaches modern European, Asian and World history. He has several international refereed publications including, 'The Italian Resistance in Piedmont: Motives and Aspirations,' International Proceedings of Economics Development and Research, Vol. 51, Humanities, Society and Culture II, edited by Han Yan, pp. 80-84. Singapore: IACSIT Press, 2012; 'Italy Rejects Her Past: Revisionists and the Anti-Fascist Foundations of the Italian Republic, Contemporary European Studies Association of Australia Review, Number 33 (May 2005), pp. 58-73; and 'Industrialists and their Support of the Early Fascist Movements in Germany and Italy: a Question of Ambivalence,' Melbourne Historical Journal, Vol. 29 (2001), pp.107-114. His current research interests include: modern Italian history and politics, with an emphasis on Italian fascism, antifascism and resistance, as well as Risorgimental studies; modern European history-with an emphasis on Germany, Russia and Spain; nineteenth and twentieth century British history; twentieth century military history; war and gender; the comparative study of fascism; labour and social history, both in Britain and Italy; oral history-particularly the relationship between memory and history; migration history (especially Italian settlement); European nationalism; and the history of civil and human rights.

Associate Professor Kelly is currently a member of the Piedmontese Institute of the History of the Resistance and Contemporary Society in Turin, Italy. 